\title{
INTELLECTUAL CAPITAL AND ABNORMAL STOCK RETURN: A CASE STUDY OF LQ-45 INDONESIA
}

\author{
Putri Aulia Kartika \\ University of Airlangga, Surabaya, East Java, Indonesia \\ E-mail: aulia.kartika.putri-2016@feb.unair.ac.id
}

\begin{abstract}
This study aims to determine the effect of intellectual capital measured using Value Added Intellectual Capital which has three components, namely Value Capital, Human Capital, and Structural Capital to the average abnormal return of shares in the LQ-45 firm. Using multiple linear regression analysis, the results showed that VACA had an effect on average abnormal return of stock and variable of VAHU and STVA had no effect to average abnormal return of stock.
\end{abstract}

\section{KEY WORDS}

Intellectual capital, capital employed, human capital, structural capital, stock return.

In the era of globalization, this era has advanced all the many sectors that have developed. Almost all sectors will be vying for the industry to increase and keep up with developments. The rapidly growing developments are identified by looking at technological advances. The existence of hard competition and according to the rules with the growth of significant innovation occurs in the business sector. Continuous development makes the company strives to continue to evaluate and improve its performance in order to survive in carrying out its business activities. Economic characteristics of knowledge base (knowledge management), asserted that a company can succeed due to the creation of transformation and capitalization of knowledge owned (Sawarjuwono and Kadir, 2003). Basic knowledge will be necessary for companies to strive to create new things and manage knowledge in order to achieve the goals of the company; a company that strives to advance will formulate and create various strategies so that knowledge can be utilized maximally and appropriately. The importance of this makes the company aware to manage the ownership of the company's resources as the most important factor in maintaining the company's advantage over its competitors.

Finally, the company transformed its strategy into knowledge based business as a way of improving the efficiency and effectiveness of other resources. The value of a company can be generated by the existence of intellectual capital that can be obtained by the company with the development of corporate culture or company's ability to motivate its employees. Many opinions that explain if the company's most valuable asset is to have Human Resources (HR) especially intellectual capital resources. All tangible assets owned by the company will be controlled by humans so that human capabilities can affect the company's operations. Current intellectual capital (IC) has been implemented to the stage of the business environment. Opportunities to be a winner in the global market will be achieved by countries that have qualified human resources (HR)

Definition of Intellectual Capital (IC) according to various sources can be interpreted that the addition of each component that can contribute value-added for the company. Intellectual Capital (IC) has three main components: (1). Human Capital (HC) presents the individual knowledge stock of an organization presented by its employees; (2). Structural Capital (SC) encompasses all non-human storehouse of knowledge within an organization as well as companies including databases, organizational charts, process manuals, strategies, routines and everything that makes the company's value greater than its material value; (3). Customer Capital (CC) is a knowledge that cannot be separated in marketing channels and customer relationship where an organization develops it through the process of doing business. These three components each have a role in creating the company's intellectual 
capital that will ultimately determine the value of the company. Ulum (2008: 78) argues that market value occurs due to the entry of the concept of intellectual capital, which is a major factor and can increase the value of the company. In line with the increasing value of the company, the company's financial performance may increase, resulting in increased corporate profits. Ramadhani (2013) explains if the profits obtained by the company can be achieved if the company's financial performance is good. Revenue generated by the company will be assessed by investors as a hope in receiving a high profit-sharing rate.

One of the strategies that must be developed when building a business in a company that is maintaining its existence by way of funding searches aimed at the basis for improvement of operational activities of the company. Issuance of shares can be one way that can be done by the company for additional funds for operating activities can be fulfilled. An investor who will invest definitely has a goal to get a return on the investment that investors place on the company. before investing requires accurate information from the company's financial statements. on the other hand, users of financial statements such as these investors need quantitative and qualitative information as an evaluation of company performance as well as information about the company's intellectual capital. Along with the increasing need for intellectual capital disclosure as a driver of corporate value while the value of difficulty in measuring intellectual capital directly arises indirect measurement of intellectual capital by using Value Added Intellectual Capital (VAIC ${ }^{\mathrm{TM}}$ ), a measure to assess the efficiency of value added as a result of the company's intellectual ability. Value Added Intellectual Capital (VAIC ${ }^{\mathrm{TM}}$ ) begins with a company's ability to create value added. Value Added (VA) is defined as the most objective measure indicator for analyzing and assessing business success as well as being able to demonstrate the company's ability to create value creation.

The emergence of the phenomenon of intellectual capital led to increased interest from many circles. They want to get a lot of information related to the management, identification, measurement, and reporting of intellectual capital. They also want more detailed, detailed and detailed information on intellectual capital analysis and its effects. Companies that have good intellectual capital performance standards will publish their own intellectual capital as a corporate advantage because high levels of disclosure can lead to higher intellectual capital performance. Finally, the investor will trust to invest in the company. When investors take investment decisions this will cause a change in stock prices dah finally affect the abnormal return of shares. Sir (2010) conducted research on intellectual capital and stock return abnormal which result showed that intellectual capital significantly influence to abnormal return of stock. Ulum Research (2008); Tan, Plowman, \& Hancock (2007); and Firrer, \& William (2003) make intellectual capital to see its influence on financial performance. This study looks at the effect of intellectual capital on the abnormal return of shares in companies listed on LQ-45 in Indonesia Stock Exchange (IDX).

\section{LITERATURE REVIEW}

Using stakeholder theory that emphasizes the position of a stakeholder who is seen as having an influence for the company. Influence created by stakeholder groups becomes an important consideration for a company in making disclosure decisions or not disclosing an information contained in the financial statements. Stakeholders are not only limited to business actors but also include shareholders of companies, communities, and environment in all aspects of the company's operations (Belkaoui, 2003).

Previous research related to intellectual capital was done by Chen, Cheng, Hwang (2005) using a Pulic model (VAIC ${ }^{\text {TM }}$ ) to test a relationship between IC and market value and company's financial performance. The results show that IC has a positive effect on the market value and financial performance of the company. In line with research conducted by Ulum (2008) related to IC and company performance using VAIC method for research in three aspects of influence, that is intellectual capital influence with company performance, financial performance of company in the future, and influence growth rate of company's 
financial performance in period which will come. The result shows that there is a significant positive correlation between intellectual capital and company performance.

This type of research is quantitative research. The sample is determined by using purposive sampling. Criteria used by researchers as follows:

- LQ-45 companies listed on the BEI have published consecutive financial statements from 2013-2015;

- LQ-45 Company is listed on IDX which distributes its shares successively from 20132015;

- The LQ-45 Company that lists salary expenses in consecutive financial statements from 2013-2015.

The data collected includes the company's annual financial report LQ-45 which is the research sample. Data collection techniques in this study using documentation techniques derived from the Capital Market Reference Center of Indonesia Stock Exchange (www.idx.co.id) and yahoo finance. This study uses independent intellectual capital variable that is measured indirectly by assessing the efficiency of value added as a result of the company's intellectual capability (Value Added Intellectual Coefficient VAIC ${ }^{\mathrm{TM}}$ ).

The main components of $\mathrm{VAIC}^{\mathrm{TM}}$ can be seen from the company's resources, namely physical capital (VACA-value added capital employed), human capital (VAHU-value added human capital), and structural capital (STVA-structural capital value added). The measurement of intellectual capital uses three proxies, namely: (1) VACA is the ratio of value added (VA) to total firm equity (CE) utilized in the fixed and current assets of a company (Pulic, 1998 in Ulum et al., 2008) (3) The STVA measures the amount of structural capital (SC) required to generate 1 rupiah of value added (VA) and is an indication of how the success of structural capital (SC) in value creation. The dependent variable is the average abnormal return of stock measured by calculating abnormal return which is the difference of the actual return with expected return calculated on a daily basis then averaged and divided by the total amount. Furthermore, all variables were analyzed using multiple linear regression analysis.

\section{RESULTS AND DISCUSSION}

Data that has been tabulated in if using SPSS Test Tools 17. SPSS test tool is used to test the influence of each independent variable VACA, VAHU, STVA to the dependent variable average abnormal return of stock. Here is the result of linear regression analysis:

Table 1 - Regression Analysis

\begin{tabular}{|c|c|c|c|c|c|}
\hline \multicolumn{2}{|c|}{ Model } & \multicolumn{2}{c|}{ Unstandardized Coefficients } & \multirow{2}{*}{ Sig. } \\
\cline { 3 - 6 } & B & B & Std. Error & & .434 \\
\hline \multirow{4}{*}{1} & Constant) & -2577.581 & 3262.877 & -.790 & .004 \\
\cline { 2 - 6 } & VACA & 8436.080 & 2770.769 & 3.045 & .258 \\
\cline { 2 - 6 } & VAHU & -.628 & .549 & -1.145 & .382 \\
\cline { 2 - 6 } & STVA & 1541.648 & 4037.144 & .382 & .704 \\
\hline
\end{tabular}

Dependent Variable: Average Abnormal Stock Return.

Table 1 shows the significance value of VACA variable of $0.004<0.05$ means that VACA affects the average abnormal return of stock. When a Capital Employed unit generates a greater return in a company than any other competitor, the company indicates that it has a better use of its Capital Employed indicator (Daud \& Amri, 2008). High VACA values have a positive relationship with return because this indicates that the tangible asset owned by the LQ-45 company is an asset that can improve the company's performance because LQ-45's corporate capital comes in the form of learning, access, and trust. When a company decides to invest from the company, the decision is based on the quality of their relationship, price, and technical specifications. The better the relationship, the greater the probability of an invasion plan occurs, and this is the greater the chance of the company to 
increase the return of external disclosure of ICs to external parties because it affects the company's stock return abnormal.

Variables VAHU and STVA have no effect on average abnormal return of stock because significance value $>$ from 0.05 is VAHU $0.258>0.05$ and STVA $0.704>0.05$. That is, the company LQ-45 tested in this study lacks Human Capital and structural capital contribution (SC) in the formation of corporate value does not affect the stock return of the company. Variable VAHU based on regression test results can be interpreted that human capital may have been maximized in the company but did not provide significant benefits in the company. this can be expected because the company does not need a new innovation that may actually exist in human capital itself. Since the LQ-45 company has high liquidity, the company's operations will continue to meet consumer demand. With this high liquidity LQ-45 is more inclined to the operational management system. Another case with the STVA variable that has no effect on the abnormal return because structural capital value added is the values of the organizational infrastructure and the type of knowledge stored in the form of manuals, guidelines, concepts, and information systems that exist in the company so as to create an effectiveness and efficiency within the company.

\section{CONCLUSION}

Based on the results of research that has been done on the influence of intellectual capital against average abnormal return of stock, it can be concluded if Value Added Capital Employed (VACA) has positive effect on abnormal return while VAHU and STVA variable have no effect to abnormal return. Generally speaking, the variables VACA <VAHU, and STVA can together affect the abnormal return. For further researcher who intend to study Intellectual Capital in more depth can add research object and classify IC in High-IC or LowIC company in one sector of company because this research use LQ-45 company where there are various kind of liquidity sector company in Indonesia.

\section{REFRENCES}

1. Abdolmohammadi, M.J. 2005. "Intellectual Capital Disclosure and Market Capitalization". Journal of Intellectual Capital. Vol. 6 No. 3. Pp. 397-416.

2. Belkaoui, R.A. 2003. "Intellectual Capital and Firm Performance of US Multinational Firms: Study of the Resource-Based and Stakeholders Views". J. of Int. Capital. 2(4): 215-226.

3. Bontis, N., 2000. Intellectual capital and Business Performance in Malaysian Industries. Journal of Intellectual Capital Vol. 1 No. 1. Pp. 85-100.

4. Brennan, N. 2000. Reporting Intellectual Capital in Annual Reports: Evidience from Ireland. Accounting, Auditing \& Accountability Journal 14 (4): 423-436.

5. Chen, M-C., S-J Cheng, dan Y Hwang. 2005. An. Empirical Investigation of the Relationship Between Intellectual Capital and Firm's Market Value and Financial Performance. Journal of Intellectual Capital Vol. 6 No. 2. Pp. 159-176.

6. Firer, Steven and S. Mitchell Williams (2003),"Intellectual Capital and Traditional Measure of Corporate Performance" Journal of Intellectual Capital. Vol. 4, No. 3. Page 348-60.

7. Ramadhani, I. (2013). Pengaruh Penerbitan Obligasi Syariah Terhadap Profitabilitas. Etikonomi, 12(2).

8. Sawarjuwono, T., 2003. Intellectual Capital: Perlakuan, Pengukuran dan Pelaporan (Sebuah Library Research). Jurnal Akuntansi dan Keuangan. Vol. 5. No. 1. pp. 31-57.

9. Sir, J., Subroto, B., \& Chandrarin, G. (2010). Intellectual Capital dan Abnormal Return Saham. Simposium Nasional Akuntansi XIII.

10. Tan, H.P., D. Plowman, dan P. Hancock. 2007. Intellectual Capital and Financial Returns of Companies. Journal of Intellectual Capital Vol.8 No.1. pp. 76-95.

11. Ulum, I., 2008. Intellectual Capital dan Kinerja Keuangan Perusahaan; Suatu Analisis dengan Pendekatan Partial Least Squares. Simposium Nasional. Pontianak: 23-24 Juli.

12. Yuniasih, N.W., D.G.Wirama, dan I.D.N. Badera. 2011. Pengaruh Modal Intelektual pada Kinerja Perusahaan. Jurnal Ilmiah Akuntansi dan Bisnis 6(2). 